\title{
The Moral Economy: Why Good Incentives Are No Substitute for Good Citizens
}

Yale University Press New Haven and London, 2016, 288 pages, ISBN: 9780300163803

\author{
Reviewed by: Javed Ahmad Khan \\ Professor, Centre for West Asian Studies \\ Jamia Millia Islamia, New Delhi, India
}

\begin{abstract}
The words 'moral' and 'economy' originated in the classical intellectual world and in Aristotle's social theory; besides the politics and ethics, economy was the third domain of practical philosophy where excessive profit making and charging of interest were not the moral practices. However, in the middle of the eighteenth century, the 'moral economy' got separated from the morality, and turned out to be simply a religious concept. Defining the moral economy in the 21st century on the basis of goodness, fairness, and justice is something perplexing for the proponents of market economies. But can we ignore the moral basis in our 'ordinary business' of life? The book under review, The Moral Economy by Samuel Bowles raises several questions in this regard and tries to show that our basic human goodness is more effective in decision making than the financial incentives. The strength of this book lies in its using different case studies and behavioral experiments with evidence-based arguments on the workable economic and financial world of the 21 st century. Islamic economics is based on morality and ethics. Thus, the purpose behind the review of this path breaking work is to understand its relevance to Islamic economics that has emerged as a new paradigm in recent decades.
\end{abstract}

Keywords: moral economy, social theory, ethics, good incentives, good citizens.

\section{Introduction}

The Moral Economy: Why Good Incentives Are No Substitute for Good Citizens is a work by an American economist Samuel Bowles who is associated with the Behavioral Sciences Program at the Santa Fe Institute in Santa Fe, New Mexico. He also taught economics at Harvard University, the University of Massachusetts. His field of specialization includes
Economic theory, Microeconomics, and Social psychology. Among his two main academic interests are, as first the co-evolution of preferences, institutions and behavior, with emphasis on the modeling and empirical study of cultural evolution, and evolution of non-self-regarding motives in explaining behavior, and applications of these studies to policy areas. The 
second is concerned with the causes and consequences of economic inequality. Besides this famous work, his related works include, The New Economics of Inequality and Redistribution (2012). His earlier work, Understanding Capitalism: Competition, Command and Change in the United States Economy (1992) deals with the issues such as competition and conflict among nations, classes and races. Bowles along with his co-economist, Herbert Gintis presented a critique of contemporary Marxian and liberal political theory in Democracy and Capitalism (1986) and examined in detail the relationship between theory and economics while exploring the multifaceted character of power in modern societies. The Moral Economy is his path breaking work.

The words 'moral' and 'economy' originated in the classical intellectual world and in Aristotle's social theory; besides the politics and ethics, economy was the third domain of practical philosophy where excessive profit making and charging of interest were not the moral practices. During the French Revolution, moral economy was associated with brotherhood and social interest. However, in the middle of the eighteenth century, the 'moral economy' got separated from the morality, and turned out to be simply a religious concept. The moral economy henceforth meant to enhance the humanitarian project with the moral dimensions.

But how the Neoclassical economics is seen, particularly after the global financial crisis of 20072008 , in which the pursuit of self-interest broke the system and, that has raised the question related to efficiency of market behavior, decision makings based on the incentives of self-interest and on the philosophy of simple monetary gain. Scholars in recent years have shown much concerns with the design of economic incentives that keep trying to figure out the right mechanism, and the proper setup, that make the self-interest of the 'nice citizens' to act for the greater human welfare. Here is a conflict between what Neoclassical economics assumes the rational calculations that maximize utility and how the behavioral economists have proven that humans are faulty at making decisions.

Economists in recent years have also shown much concern with regard to the human-behavioral aspects where both the incentives, and the moral and human behavior get prime importance. In fact, the ideal world of laissez faire never existed and following World War II, gradually the 'New Economics' emerged, while adopting the 'middle way' from the capitalism and socialism, turned into the mixed economy.

Defining the moral economy in the $21^{\text {st }}$ century on the basis of goodness, fairness, and justice is something perplexing for the proponents of market economies. It can be seen that the freedom of choice in the presence of ethical dilemmas is beyond rationality and neither idealism nor pragmatic being able to determine it alone.

But can we ignore the moral basis in our 'ordinary business' of life? The book under review, The Moral Economy by Samuel Bowles raises several questions in this regard and tries to show that our basic human goodness is more effective in decision making than the financial incentives while self-interested and amoral attitudes aren't as such effective in real life. Incentives work and often affect behavior almost exactly as conventional economic theory predicts, that is, by assuming that the target of the incentive cares only about his/her material gain.

In this context, one basic question addressed in the book is whether the concept of self-interest and ethical aspects of economics can work together? In other words, how the individual's utility maximization and altruistic concern for others can be visualized in a social science framework? Should the idea of the economic man - the amoral and selfinterested homo economicus - determine how we expect people to respond to monetary rewards, punishments, and other incentives? Further, how the economic man, at the same time can integrate the moral norms and ethical values of the society? Bowles convincingly argues that economic incentives and legal constraints alone will not produce a flourishing society because good, morally motivated, people are indispensable.

The author provides evidences to prove that "why do policies and business practices that ignore the moral and generous side of human nature often fail'. As indicated by the subtitle, "Why Good Incentives Are No Substitute for Good Citizens", he urges us to question the utility of employing financial rewards 
and punishments instead of appealing to our basic human goodness. He explains this with an example.

\begin{abstract}
In Haifa, at six day care centers, where a fine was imposed on parents who were late in picking up their children at the end of the day. It did not work. Parents responded to the fine by doubling the fraction of time they arrived late. After twelve weeks, the fine was revoked, but the parents' enhanced tardiness persisted. The counterproductive result of imposing these fines suggests a kind of negative synergy between economic incentives and moral behavior. Placing a price on lateness, as if putting it up for sale, seems to have undermined the parents' sense of ethical obligation to avoid inconveniencing the teachers, leading them to think of lateness as just another commodity they could purchase. (p. 19)
\end{abstract}

He attacks the core of Jean-Jacques Rousseau's "Social Contract", an injunction to treat "men as they are" that takes for granted that we are self-interested and amoral. This assumption underlies much of our public policy, legal systems, and organizational design today, and as a result, as Bowles says,

material incentives are now deployed to motivate student learning, teacher effectiveness, weight loss, voting, smoking cessations, the switch from plastic grocery bags to reusable ones, fiduciary responsibility in financial management, and basic research. All are activities that, in the absence of economic incentives might be motivated by intrinsic ethical or other non-economic reasons. Moreover, fines, rewards, and other material inducement often do not work very well. (p. 16)

After all, moral and ethical aspects cannot be ignored even in a competitive market economic framework. However, for an efficient market economy to work, it is always the trust in human goodness and that is the reason it looks more ideological than practical in a real-life situation. This also supports the arguments that in human behavior analysis, the laws imposed are not as much effective as right conducts, and morality that play a greater role.

This book breaks that path of conventional economic thinking where economic rationality dominates in the decision-making process. On the contrary, Bowles argues with evidence that virtue has a place in economics and that selfishness is not the only human characteristic in the real world. Thus, instead of the self-interest-centered approach in any policy design, the author argues for a synthetic app- roach where both self-interest and social-preferences work simultaneously.

In chapter three, the author goes on with conceptual details and brings evidences. A moral economy, is an economy that is generally only stable in small, closely knit communities, where the principles of mutuality work. But how to measure the viability of this in a globalized world where human contacts are seen less and less? However, while arguing for moral and ethical behavior in decision making, the author is a hardcore defender of the social sciences in economic paradigm. He argues much convincingly that different customs and political cultures influence and condition incentives. However, in the book he is proposing a paradigm shift in how we think about our lives and about economics and explores how the actions we take are motivated by their meaning. The author emphasizes the importance of this not only in the area of business and finance but also for political leaders, policy makers, and social scientists to understand the issues because material incentives, such as taxes, fines, or subsidies, have not been much effective in solving the contemporary market failure. The author has excessive evidence which sometimes gives rise to confusion whether such evidence would be compatible to a market based global economy?

For a common man, this provides an insight in understanding the relevance of self-interest and values in decision making in the area of economics and finance. It gives new direction for the policy makers also. However, Bowles' plea to pay attention to social preferences also points towards practical problems, as capitalistic social institutions are based on monetary motives. In this regard, he has argued that such policies and economic decision making often turns into failure. Here, the author clearly discovers the self-interested homo-economicus to policy making process. He rightly asks "why should we assure in advance that people for whom policies are being framed are necessarily selfish in their nature" (p. 15). Using historical and recent case studies as well as behavioral experiments, the author shows how well-designed incentives can crowd in the civic motives on which good governance depends.

Moreover, despite that the author was excessively repetitive in this regard, one must ask how morals and markets would be interrelated? How the right 
combination between moral behavior and economic performance can be used not only to maintain freedom and order but also to create common wealth? No doubt, incentives were deemed crucial to steer interests and passions in the right direction.

But how the material incentives and social preferences can work together? In chapter five, the author illustrates the example of Denmark and UK., who are confronted with abundant material incentives, yet still show strong social preferences. Here he demonstrates that in liberal societies rules of law, rather than the market, influence civic preferences. This further leads the author to argue (in chapter six) that material incentives are necessary but not sufficient for a wellgoverned society. Bowles mentions some other case studies to prove that incentives and social preferences are an ungainly mix when incentives were not accompanied by a "moral message" (p. 203).

This book also focuses on the crisis of modern times prevailing under the capitalism, though the author does not out rightly reject capitalism but raises the issues of its understanding of human nature. It compares and contrasts economic assumptions about human behavior in conventional economics. He also explains the 2008 financial crisis through a comprehensive theory of human nature. It can be seen that in the current economic literature, there is an increasing focus on the behavioral aspects of conventional economics as a study of psychology as it relates to the economic decision-making processes of individuals and institutions. This points that people would always make optimal decisions that provide them with the greatest benefit and satisfaction. In economics, rational choice theory also states that when humans are presented with various options under the conditions of scarcity, they would choose the option that maximizes their individual satisfaction. The rational person has self-control and is unmoved by emotions and external factors and, hence, knows what is best for himself. Behavioral economics extends economic principles by allowing that our decisions are affected by social and psychological influences, as well as rational calculations of benefits and costs. This enriches our understanding of economic and financial behavior, without necessarily abandoning the analytical power often associated with conventional economics.
This book also helps us to understand the financial crisis of 2008 that occurred due to the irrational aspect of human behavior, especially of the political leaders' decision making, without taking into consideration the moral and ethical aspects related to unethical conspicuous consumerism. Interestingly, during the financial crisis of 2008, when the borrowers of the funds could not return the loans, the banks started to use moral slogans as a strategy to recover from the defaulters. This however did not work. The argument is that incentives are not much effective on the individual or group's decision making. Though incentives are still the backbone of market economies in the capitalistic framework. (p. 301)

The financial crisis of 2007-2008 and its aftermath have led to a debate about the need to consider the role of ethics and morality in the economic and financial workings of contemporary capitalism. Such crises could have been avoided if there were strong ethics embedded in financial transactions, public policy, regulations, governance, and business leadership.

Here, the book shows us how economic decisions are influenced by other than self-interest, by social norms and preferences, and that economic incentives and legal constraints will not be solely effective in economic or financial decision making. As the author shows, there is strong evidence that moral and ethical factors motivate the individuals in their decision making. But the way Bowles has demonstrated this is worth noting as he explains this with intellectual breadth and analytical acuity.

The strength of this book lies in its using different case studies and behavioral experiments with evidence-based arguments on the workable economic and financial world of the $21^{\text {st }}$ century. The author addresses both the common citizens and policymakers alike. It is however not much clear how these moral principles and ethical values can be effective in an overall competitive macroeconomic framework, and if the religiosity can influence the behavior of investors, how the fitness of the "economic man" can be analyzed in a global financial market?

Islamic economics is based on morality and ethics. Thus, the purpose behind the review of this path breaking work is to understand its relevance to Islamic economics that has emerged as a new para- 
digm in recent decades and the ongoing rigorous analysis on its diverse field of researches can be seen in the form of books, scientific research papers, and $\mathrm{PhD}$ theses in prestigious universities and research centers around the globe.

Although the author has not given any direct reference to the philosophy of Islamic economics and financial system in this work, he has repeatedly argued about the importance of cultural values in other societies that have developed market institutions working as more ethical-based rather than purely on self-interest. Many classical Islamic economic thinkers also drew on the great Hellenic philosophers of the antiquity. In line with Aristotle, they treated greed, avarice, deceit, corruption, and oppression as traits that could be overcome, to one degree or another, through moral education. But why the philosophy of Islamic economics could not be implemented with the passage of time in the recent past? The answer given is that the half-century leading up to World War II constituted a period of nearcomplete separation between religious and economic thought in the Muslim world.

For an Islamic man, incentives are derived from the Sharī'ah and Islamic economic hypotheses have to be based on assumptions derived from Sharī'ah laws and its social welfare values above material gains where emphasis is placed on rewards in life after death. In traditional Islamic society, financial and economic activities were based on ethics derived from the Shari'ah. These realities persisted into modern times and, although weakened, have not disappeared completely even now. But how far this

\section{References}

Bowles, S., \& Gintis, H. (1986). Democracy and capitalism: property, community, and the contradictions of modern social thought. New York: Basic Books.

Bowles, S., \& Edwards, R. (1992). Understanding Capitalism: Competition, Command and Change in the United States Economy. Boston, MA: Addison-Wesley Educational Publishers. book supports the basic philosophy of Islamic economics and finance? We have still not much empirical evidence to argue for the viability of this emerging paradigm in a social science framework. In this context, this work invites the academics and researchers to compare the moral economy under capitalism in modern times with the Islamic economic paradigm.

Samuel Bowles' work may also help us in understanding the philosophy of Islamic economics where the basic emphasis is on ethical consideration, altruism, promoting equity and justice towards deserving and not to one maximizing only one's own material benefits. These ideas provide interesting implications for the normative debates with moral responsibilities in business and financial markets. This book, in a way, puts the case of Islamic economics as a viable alternative to conventional economics in present times that can be further researched and explored.

In an Islamic economics framework, however, as Umar Chapra points out that incentives are to realize the maqāṣid al-Sharī'ah. "If, however, the supremacy of moral values is not recognized collectively, more and more regulations may have to be enacted and enforced, at a prohibitive economic cost" (Chapra, 1992, pp. 42-43).

The main conclusion drawn from Bowles' book is that there is a need for re-examination of core economic and financial theories and assumptions in the light of morals and ethics, which could make the economics finance more responsible in the $21^{\text {st }}$ century.

Bowles, S. (2012). The New Economics of Inequality and Redistribution. Cambridge, UK: Cambridge University Press.

Chapra, M.U. (1992). Islam and the Economic Challenge. Leicester, UK: The Islamic Foundation. 
Javed Ahmad Khan is a Professor and Officiating Director at the Centre For West Asian Studies in Jamia Millia Islamia, a Central University at New Delhi. He has a $\mathrm{Ph} . \mathrm{D}$. in Islamic Economics and is currently engaged in teaching and researches in Islamic economics and finance. Previously he has been associated with the Centre of West Asian Studies, Aligarh Muslim University, India (1990-1996). His publications include; Islamic Banking in India: Scopes and Challenges (Edited, 2003), Islamic Economics and Finance: A Bibliography (1995), India and West Asia - Emerging Market in the Liberalization Era (1999). He also edited a bimonthly Islamic Economics Bulletin (1991-2003). His areas of academic interest include Indo-Arab Economic Relations, Arab Economies and Islamic Finance.

E-mail: jkhan2@jmi.ac.in. 


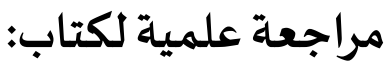

الاقتصاد الأخلاقي: لماذا الحو افز الجيدة ليست بديالاًللمواطنين الجيدين

\author{
المؤلف: سـامويل باولز
}

الناشر: مطابع جامعة ييل، نيو هيفن، الولايات المتحدة الأمريكية ، 2016م ، 288 صفحات

\author{
مراجعة : جاويد أحمد خان \\ أستاذ، مركز دراسات غرب آسيا، جامعة ملية إسلامية، نيو دلهي، الهند
}

المستخلص. نشأت الكلمات "الأخلاق" و "الاقتصاد" في عالم الفكر الكلاسيكي وفي النظرية الاجتماعية لأرسطو؛ إلى جانب السياسة والأخلاقيات (ethics)، كان الاقتصاد هو المجال الثالث للفلسفة العملية العالية

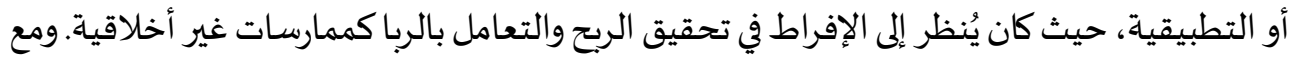

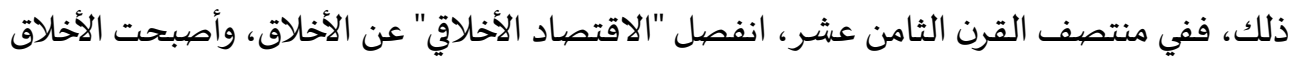

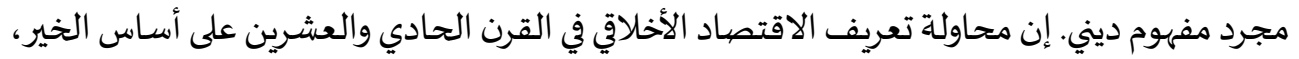

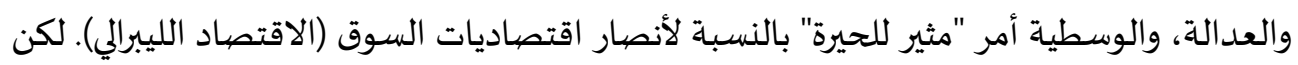

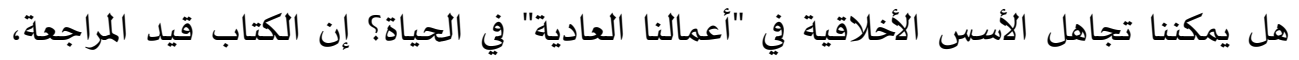

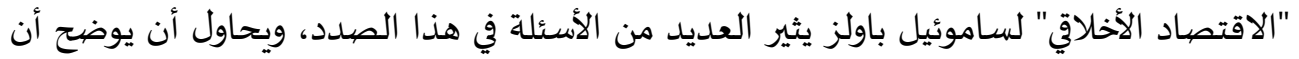

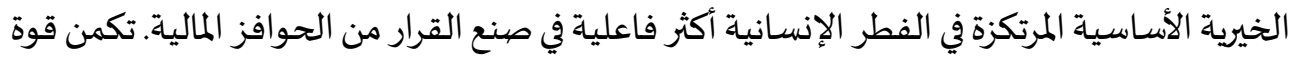

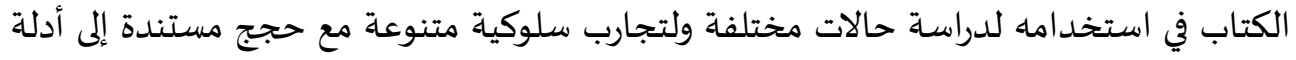

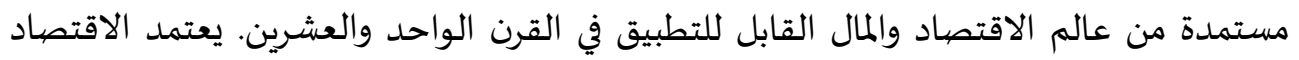

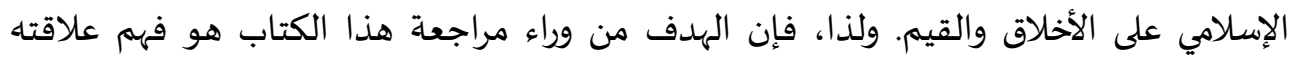

$$
\text { بالاقتصاد الإسلامي التي برزت كنموذج جديد في العقود الأخيرة. }
$$

الكلمات الدَّالة: الاقتصاد الأخلاقي، النظرية الاجتماعية، الأخلاقيات، الحوافز الجيدة، المواطنون 